\title{
Can Changes in Soil Properties in Organic Banana Production Suppress Fusarium Wilt?
}

\author{
Paul Geense1, Anthony B. Pattison'2*, Tegan L. Kukulies², Johannes M. S. Scholberg1, \\ Agustin B. Molina ${ }^{3}$ \\ ${ }^{1}$ Farming Systems Ecology, Wageningen University, Wageningen, The Netherlands \\ ${ }^{2}$ Agri-Science Queensland, Department of Agriculture, Fisheries and Forestry, South Johnstone, Australia \\ ${ }^{3}$ Bioversity International, Los Baños, Philippines \\ Email: ${ }^{\text {Tony.Pattison@daff.qld.gov.au }}$
}

Received 20 February 2015; accepted 9 March 2015; published 13 March 2015

Copyright (C) 2015 by authors and Scientific Research Publishing Inc.

This work is licensed under the Creative Commons Attribution International License (CC BY).

http://creativecommons.org/licenses/by/4.0/

(c) (i) Open Access

\section{Abstract}

Organic agriculture promotes disease suppression through healthy soils by increasing biological activity and diversity through the application of organic fertilizers and increasing organic inputs. Fusarium wilt of bananas (Fusarium oxysporum f. sp. cubense) (Foc), also known as Panama disease, has been a devastating disease throughout the world. So far, no fungicides or cultural measures have been found that control Foc sufficiently. The aim of this research was to assess whether organic-based farming systems were more resilient than inorganic farming systems to soil borne diseases, in particular Fusarium wilts. A survey was conducted comparing five organic and five conventional banana plantations at paired sites in north Queensland, Australia. Soil samples were collected and analysed for chemical, physical and biological soil health indicators. Disease development of $F$. oxysporum f. sp. lycopersici in tomatoes and Foc in bananas were studied in pot trials to pursue clues for identifying Fusarium suppressive soil traits. Organic soils from the survey showed higher microbial activity and lower disease symptom expression (both with tomatoes and bananas) than conventional soils. In the survey, nematode diversity and soil sulphate content were recurring indicators in all experiments showing close correlations to pathogen growth, disease expression and plant health. Organic soils were lower in plant-parasitic nematodes and sulphate sulphur levels and higher in nematode diversity, labile soil $\mathrm{C}$ and microbial indicators. Soil conduciveness or suppression of Foc appeared to be largely governed by competition for carbon. Measurement of soil microbial enzyme activity, nematode community structure and diversity and possibly sulphate sulphur seem to provide a relatively reliable indicator for general disease suppression. Differences between organic and conventional agriculture cannot be related to single management practices, but may be linked to synergies among system components.

"Corresponding author. 


\section{Keywords}

\section{Disease Suppression, Fusarium oxysporum f. sp. cubense, Musa spp., Organic Banana Systems, Microbial Activity, Soil Nematode Community}

\section{Introduction}

The Australian banana industry produced 285,535 tonnes, valued at AU \$565 million, from 13,496 ha in 2012 (FAOSTAT, 2014). In 2012, Australia was the 37th largest producing nation of bananas in terms of production, but the 41st largest producer in terms of area and the 50th nation in terms of yield (FAOSTAT, 2014). Due to its favourable climate most of the Australian banana production occurs in north Queensland (93\%), which produces about AU \$400 million annually, with smaller production areas located in the sub-tropics of Western Australia, northern New South Wales and south-east Queensland and in the tropics around Darwin in the Northern Territory. Banana production in Australia is primarily for domestic consumption.

The banana farms of north Queensland are mainly family-based businesses with a typical farm size of 15 to 20 ha, although some plantations are as large as 500 ha [1]. Production in north Queensland is about $30-40$ $\mathrm{t} \cdot \mathrm{ha} \cdot \mathrm{yr}^{-1}$, which is characterised by a high level of technology and mechanisation relative to other banana producing countries due to high labour costs [1]. Agrochemicals are commonly used against weeds, bunch pests, foliar diseases and soil-borne pests and diseases. The use of a spraying calendar is still widespread, but there is increasing attention, by governmental regulations and policies, to promote integrated pest management (IPM) [2]. In recent years there has been increasing concern about erosion and runoff of agrochemicals, nutrients and sediments, which may pollute rivers and other ecosystems [1] [3]-[5]. The tropical banana industry in Queensland was identified as a contributor of nutrients and sediments to waterways and the Great Barrier Reef lagoon [3] [6] [7]. Sustainability and soil health are now key focal points of the Australian banana industry to improve soilbased resources [4] [5].

Fusarium wilt of bananas (Fusarium oxysporum f. sp. cubense (Foc)), also known as Panama disease, has been one of the most devastating crop diseases known [8]-[10]. Foc survives in the soil saprophytically, by chlamydospores and micro- and macro-conidia. The chlamydospores can survive in the soil for several years [11]. Currently, there are four races of Foc; Race 1 affects bananas of the Gros Michel, Sugar and Pome varieties, Race 2 affects Bluggoe and related cooking bananas, Race 3 affects Heliconia spp., but is not pathogenic to bananas and Race 4 affects varieties from the Cavendish group, with a distinction between sub-tropical and tropical Race 4 (TR4) [12]-[14]. Fusarium wilt of bananas has been reported in Australia as early as 1874 [15]. However, not all races of the pathogen are present in all production areas, with TR4 being confined to the Darwin region in the Northern Territory [16] [17]. In north Queensland Cavendish cultivars are most commonly grown, which are resistant to Foc Race 1, but there is also production of niche cultivars, Ladyfinger (a Pome variety, Musa AAB) and Ducasse (synonym PisangAwak, Musa ABB), which are susceptible to Race 1 [8].

There is growing concern that monoculture of bananas, using the same clone renders commercial banana production systems more susceptible to pests and diseases due to lack of diversity [18] [19]. Moreover, there is a need to address problems in the banana industry such as soil erosion, ecosystem contamination and incidence of pests and diseases, which may be accomplished by using integrated approaches. Organic agriculture is a way of farming that aims to integrate and manage these aspects in an ecological sound system [20] [21]. Organic agriculture aims to achieve disease control through promoting healthy soils featuring enhanced biological activity and thus improved soil suppression of soil-borne pests and diseases. This may be realised by application of organic amendments instead of synthetic fertilizers, thereby stimulating soil microbial biomass and activity [22][24]. Moreover, organic agriculture aims to maintain or increase above- and below-ground biodiversity by more effectively employing crop rotation and intercropping techniques compared to conventional systems. However, very little literature is available on organic banana production in north Queensland or in Australia in general. One reason for this might be that there is no systematic collection of data on organic agriculture at the national level [25]. Although, the organic banana sector is still very small compared to the conventional sector, current knowledge gaps tend to hamper any future expansion.

For the banana industry to improve soil management there is a need to develop indicators that are able to 
quantify changes in soil properties and which may be used to design and promote improved land management practices. Such indicators should encompass a holistic view of soil management techniques and account for changes in physical, chemical and biological soil properties [26]. A better understanding of the soil ecosystem may result in development of a stable, resilient soil system that is able to recover from stress, and demonstrates enhanced biological diversity and more efficient internal nutrient cycling [27]. A selection of soil health indicators for use in the banana industry was developed by Pattison et al. [4], using physical and chemical indicators, plus soil nematode community structure. However, there needs to be more extensive verification that changes in crop management such as organic production can result in improved soil health characteristics including the suppression of soil borne diseases such as Foc.

Considering the need for a durable management tool for controlling Foc that does not negatively impact on control of other diseases or the environment, this study looks at organic agriculture as a sustainable option to reduce Foc disease incidence. According to Alabouvette [28] and Alabouvette et al. [29], soil suppression to Fusarium wilt is general to Fusarium oxysporum and not specific to certain formae speciales of the fungus. This study aimed to investigate the potential benefits of organic banana production systems through a combination of both a farm survey along with glasshouse experiments. The hypothesis for the research was that organic agriculture altered soil health indicators under bananas by improving microbial activity and diversity relative to conventional banana production, resulting in more resilient soil properties that could suppress biotic stresses such as Foc. To test the hypothesis organic and conventional banana production systems were surveyed to compare physical, chemical and biological soil health indicators, followed by different screening methods for comparing soil borne disease suppression.

\section{Materials and Methods}

\subsection{Site Selection and Soil Sampling}

The area under survey covered tropical north Queensland, banana production area south of Cairns and north of Cardwell, and the Atherton Tablelands. Five organic and five conventional banana farms were selected as paired sites. Selection of organic sites was based on willingness of the farmers to cooperate, while the potential number of available organic farms was rather limited. The conventional sites were selected based on proximity to the organic sites in order to reduce pedo-climatic variation among sites [4] [30]. Observations were made on management practices and soil descriptions from each site were based on the Australian soil classification system [31], with soil characteristics for drainage and erosion hazard based on SafeGauge [32]. From each site, three banana fields with plantings generally older than five years were sampled and soil samples analysed separately for each field.

Soil samples were collected using a shovel to remove a square block of soil approximately $15 \mathrm{~cm} \times 15 \mathrm{~cm}$ to a depth of $15 \mathrm{~cm}$ within $30 \mathrm{~cm}$ from the base of the banana plant, in front of the following sucker to form a composite soil sample $(n=15)$ from each field. Stones and large pieces of organic matter were avoided during sampling. Soil was placed in a bucket and thoroughly mixed with a trowel.

\subsection{Soil Analysis}

Collected bulked soil samples were analysed for physical, chemical and biological soil health indicators and samples were sent to a commercial laboratory, Incitec Pivot Ltd., Weribbee, Victoria, Australia, for further chemical analysis. The following soil health indicators were measured at the Department of Agriculture, Fisheries and Forestry Laboratory at South Johnstone: $\mathrm{pH}$, electrical conductivity (EC), nitrate nitrogen $\left(\mathrm{NO}_{3}-\mathrm{N}\right)$, labile C, fluorescein diacetate, $\beta$-glucosidase, bulk density, water stable aggregates (WSA), soil particle size and nematode community structure. Soil $\mathrm{pH}, \mathrm{EC}$ and $\mathrm{NO}_{3}-\mathrm{N}$ were determined by mixing the soil in water (1 part soil to 5 parts water) and determining values of the suspended solution using a pH and EC multi probe (TPS WP-90) and $\mathrm{NO}_{3}-\mathrm{N}$ test strips using the Merck Reflectoquant system with RQflex reflectometer (Merck KGaA, Darmstadt, Germany). Labile carbon contents were determined by measuring the amount of C oxidised by $33 \mathrm{mM} \mathrm{KMnO}_{4}$ in duplicate $5 \mathrm{~g}$ sub-samples using the method described by Moody and Cong [33]. Similarly, fluorescein diacetate (FDA) hydrolysis rate was determined from duplicate $5 \mathrm{~g}$ sub-samples using a modified version of the method initially proposed by Schnürer and Rosswall [34]. $\beta$-glucosidase was determined with the procedure published by Eivazi and Tabatabai [35] except the toluene was substituted with $0.1 \%$ Tween solution and the mod- 
ified universal buffer was replaced with a McIlvaine buffer (pH 6.0).

Soil nematodes were extracted using a modified Baermann funnel technique [36]. A $200 \mathrm{~g}$ sample of field soil maintained at the soil moisture capacity at the time of sampling was weighed onto a mesh sieve with a single ply of tissue and then placed into a tray with $250 \mathrm{~mL}$ of water and left for 48 hours. The nematodes were collected on a $25 \mu \mathrm{m}$ sieve and backwashed into a vial. The total number of nematodes in the $200 \mathrm{~g}$ soil sample was determined on a counting slide and expressed as the number per $100 \mathrm{~g}$ of soil. A $50 \mu \mathrm{L}$ aliquot was placed on a glass slide, with a minimum of 100 individual nematodes identified to genus level for plant-parasites and to the family level for free-living nematodes. Soil nematode community analysis was made on soil nematode trophic groups (parasites, fungivores, bacterivores, omnivores and predators).

Indices of the nematode community composition were calculated from the number of nematode taxa extracted from each plot. Nematode diversity was determined using the Shannon-Weiner index [37]. The bacterivore to fungivore ratio was calculated from the total abundance of bacterivores (B) and fungivores (F) (B/(B + F)) [37]. Additionally, the weighted functional guilds concept was applied, without plant-parasites. The nematode functional guilds were used to calculate the basal, enrichment index (EI), structure index (SI) and channel index (CI) of the soil food web [38]. Plant-parasitic nematodes were identified to species level where possible and the abundance of each individual classification of plant-parasitic nematode was kept separate.

\subsection{Bioassays for Assessing Soil Suppression of Fusarium spp.}

Hyphal extension was determined by growing Foc R1 on collected soil samples on laboratory plates in an incubator [29]. Petri dishes were filled with $30 \mathrm{~g}$ of $2 \mathrm{~mm}$ sieved air dried soil which was spread evenly to obtain a smooth surface (approximate bulk density $=1.0 \mathrm{~g} \mathrm{~cm}^{3}$ ). Sterile water $(12 \mathrm{~mL}$ ) was added to each Petri dish. Wetted soils were left to equilibrate for 7 days in the incubator. Using Foc R1 (VCG 0124) cultures on 1/4 strength Potato Dextrose Agar (PDA) a $1 \mathrm{~cm}$ diameter, $4 \mathrm{~mm}$ thick plug from the growing margin of the fungal colony was inverted and placed centrally on top of the soil in the Petri dishes. After one week the number of plugs that had hyphae growing on the soil surface was recorded. Each week for 4 weeks of incubation at $25^{\circ} \mathrm{C}$, the extension of the mycelium was determined using a binocular microscope and the area of hyphal extension was estimated for a 4-week period. The Petri dishes were maintained at $25^{\circ} \mathrm{C}$ during this period. A rating system was used to give a one number score for extent of hyphal growth, such that: $1=$ less that 5 hyphae and hyphae < $1 \mathrm{~cm}, 2=$ more than 5 hyphae and hyphae $<1 \mathrm{~cm}, 3=$ less than 5 hyphae and hyphae $>1 \mathrm{~cm}, 4=$ more than 5 hyphae and hyphae $>1 \mathrm{~cm}$ and $5=$ extensive hyphal growth. The test was replicated 5 times per soil sample. The area under the (growth) curve (AUC) for each plate was estimated in Genstat (Edition 11). The AUC values were then statistically analysed using a one-way-ANOVA and tests of multiple comparison of means (Fisher's protected LSD test with $p=0.05$ ) to assess differences in suppression of Foc hyphal extension between collected samples.

A glasshouse bioassays using tomato (Solanum lycopersicum cv. Tasty Tiny Tim) with its associated Fusarium pathogen, Fusarium oxysporum f. sp. lycopersici R3 (Fol R3) was used for the assays. Polystyrene trays $(72 \times 20 \times 7 \mathrm{~cm})$ with 5 rows of 18 cells were used for the bioassay. Each cell was $4 \mathrm{~cm}^{2}$ at the top and narrowing down to $5 \mathrm{~mm}^{2}$ at the bottom allowing for good drainage but preventing soil from dropping out. To each cell $45 \mathrm{~cm}^{3}$ of soil was added, equivalent to $50 \mathrm{~g}$ of soil. Two inoculation methods were used; inoculation with spore solution in liquid malt extract and inoculation with colonised milled seed.

One litre of liquid malt extract was inoculated with one plug of agar from the edge of a Fol R3 colony and placed on a rotary shaker (150 rpm) for seven days. After four days the solution was placed under near UV light for five hours to stimulate sporulation and placed back on the shaker. The solution was sieved through a sterile funnel $(40 \mu \mathrm{m})$ and diluted to $10^{3}, 10^{4}$ and $10^{5}$ concentrations. Soil samples of organic and conventional soils were infested with $4 \mathrm{ml}$ of malt-based inoculum suspension at concentrations of $1 \times 10^{3}, 10^{4}, 10^{5}$ propagules $\mathrm{ml}^{-1}$ soil. Controls received $4 \mathrm{ml}$ of tap water and each treatment was repeated five times. Non-inoculated controls were included for both organic and conventional systems.

Millet seed (500 g) was placed in Erlenmeyer flasks, soaked in water for 24 hours and sterilised by autoclaving. The flasks were inoculated with agar plugs of Fol R3 from the edge of a colony. The flasks were incubated at room temperature for 14 days and were mixed daily by hand shaking. Colonised millet seed was added to 45 $\mathrm{ml}$ of soil at rates of $0.5,1.0$ and 1.5 grams of inoculum and thoroughly mixed with approximately $50 \mathrm{~g}$ of soil. Each treatment was replicated five times. Non-inoculated controls were included for both organic and conven- 
tional systems. One-week-old susceptible tomato seedlings were planted into each cell. Plants were kept in a greenhouse under controlled conditions with air temperatures maintained at $27^{\circ} \mathrm{C}-32^{\circ} \mathrm{C}, 70 \%-80 \%$ relative humidity, and $12 \mathrm{~h}$ sunlight per day and watered once a day throughout the experiment.

Disease progress was recorded twice a week from 21 to 58 days after sowing. The following rating system was used: 1 = healthy plant, 2 = wilting of lower leaves, $3=$ whole plant affected and $4=$ plant dead/terminal wilting. Since the tests were done with unsterilized soil from various farms, PDA-plate isolation was done from the roots of each dead plant to determine whether death was caused by Fusarium spp. or by another pathogen. At the termination of the experiments diseased plants were used for pathogen isolation. Randomly selected healthy plants were also used in isolations to determine the presence of Fol R3. The AUC for each plant was estimated in Genstat (Edition 11). The AUC values were statically analysed using a one-way-ANOVA and multiple means comparison (Fisher's protected LSD test with $p=0.05$ ). Disease incidence, growth and soil health indicators were tested on two-sided correlations.

Isolation of organisms from dead, diseased and healthy plants were conducted by taking plants from the trays and carefully washing the roots and lower stems. Roots and stems were dipped for 30 sec in 1\% bleach solution to remove fungi and bacteria growing on the surface of the plant tissue before being rinsed in sterilised water. The roots and stems were then cut into small $(<0.5 \mathrm{~cm})$ sections and a placed on $1 / 4$ strength potato dextrose agar (PDA) in an incubator at $27^{\circ} \mathrm{C}$. When the colonies were approximately $1 \mathrm{~cm}$ in diameter the plates were taken from the incubator and placed under UV light at $23^{\circ} \mathrm{C}$ to allow morphological characteristics to be identified.

A pot experiment with bananas was conducted to determine whether the previous bioassays for assessing disease suppression provided a good indication of suppression to Foc R1. For this experiment soil from paired organic and conventional sites from the farm survey, which were determined to have the greatest potential for Foc suppression and the least potential for Foc disease suppression were used. Therefore, four farms were selected using soil collected from the three fields from each farm, with a Foc inoculated treatment and uninoculated control from each field. Each treatment had two replicates, making 48 pots in total, which were randomised using a split plot design.

Soils were inoculated with Foc R1 (VCG 0124) colonised millet seed. Millet seed (500 g) was placed in Erlenmeyer flasks, soaked in water for 24 hours and sterilised by autoclaving. The flasks were left at room temperature to incubate for 14 days and were mixed daily by hand shaking. Approximately $1.5 \mathrm{~kg}$ of soil was weighed and placed in plastic bags and $10 \mathrm{~g}$ inoculum was added to the soil in each bag. After thorough mixing, the soil was placed in $2 \mathrm{~L}$ pots. Control pots were filled with $1.5 \mathrm{~kg}$ non-inoculated soil.

Tissue cultured Ducasse (Musa AAB) banana transplants were placed in the pots. The pots were placed on trays and soil moisture content was kept constant by filling the bottom of the trays with water. At five weeks post planting, the trays were left dry for 24 hours to create more favourable circumstances for the disease symptom expression. Each pot received $5 \mathrm{ml}$ of organic liquid blood and bone meal (dilution 1/100) once a week.

Disease progress was recorded once a week from day 21 to day 58 post inoculation. Plant wilting was recorded following a rating system of 1 - 5 developed by INIBAP [39], where: 1 = plant healthy, 2 = slight yellowing or wilting of lower leaves, 3 = extensive yellowing or wilting of lower leaves, $4=$ yellowing or wilting of most or all of the leaves and $5=$ plant death. Leaf emergence and growth were measured every two weeks. At the end of the trial the leaf area of the last fully emerged leaf was estimated as in described by Turner [40], and the corm was dissected to assess vascular discoloration on a rating of 1-6 according to the INIBAP guidelines [39], where: 1 = rhizome completely clean, 2 = isolated points of discoloration, 3 = vascular discoloration of up to $1 / 3$ of rhizome, $4=$ discoloration affecting between $1 / 3$ and $2 / 3$ of rhizome, $5=$ greater than $2 / 3$ of rhizome discoloured and $6=$ total discoloration rhizome vascular tissue. At termination of the trial, the number of discoloured roots was counted from a random sample of five roots. Soil was washed from roots and corm. Roots, corm and leaves were separately dried in a drying oven for seven days at $75^{\circ} \mathrm{C}$.

\subsection{Statistics}

Soil parameters from banana survey sites were analysed using a one-way analysis of variance (ANOVA). Each pair of sites formed a replicate, with two treatments either organic or conventional. Fields within each site formed sub-samples for each treatment. Where significant $\mathrm{F}$ values $(p<0.05)$ were obtained between treatments, means were separated using Fisher's protected LSD method. The area under the curve (AUC) for hyphal growth of FOC and wilting symptoms of tomato and banana was estimated in Genstat (Edition 11). The AUC values 
were then statistically analysed using a one-way-ANOVA and tests of multiple comparison of means (Fisher's protected LSD test with $p=0.05$ ) to assess differences in suppression of between sites. Disease, growth and soil health indicators were tested using a two-sided t-test for correlation and a stepwise multiple regression calculated for soil parameters related to the AUC for Foc hyphal growth and tomato wilt symptoms. The dimensionality of the original data set was reduced by using principal component analysis (PCA), which was performed on those disease indicators associated with Foc of bananas. The PCA was based on the correlation matrix and a varimax factor rotation and results were used to increase the interpretability of the principal components and the construction of a bioplot. All statistical analyses were performed in GenStat for Windows 11th Edition [41].

\section{Results}

\subsection{Banana Site Survey}

Three of five pairs of farms were situated in the wet tropical coastal zone of north Queensland (Table 1). One pair of sites was slightly more inland in the southern zone, which received lower rainfall on an alluvial Dermosol (Table 1). The fifth pair was situated in the Atherton tablelands where both temperatures and rainfall are considerably lower (Table 1). There were visible differences observed among organic and conventional farms in terms of weed and ground cover management. One organic farm used paper and cardboard as mulch but still showed a high incidence of weed growth, while another farm employed a very thick layer of leaf mulch resulting in little weed growth. A third farm had a dense ground cover of pinto peanut (Arachis pintoi), whereas another farm used weed mats. Lastly, one organic farm used a rotation system of three-year production and twoyear fallow. Some organic farms put the banana crop residue in the rows in line with banana plants and others in the inter-rows. All organic farms had densely vegetated inter-rows, mainly grass and, in one instance, pinto peanut. The conventional farms tended not to use ground cover, with only one farm having densely vegetated interrows. Banana crop residue was used as mulch in the rows of one farm, while at most farms banana crop residue was left in the field where it dropped.

There were no significant differences $(p>0.05)$ in physical soil health indicators between organic and conventional soils (Table 2). Based on the similarity of the sand, silt and clay fractions between organic and conventional soils it appeared there were no major difference in soil types between the two management systems for paired sites. Bulk density and WSA did not show difference between the two systems. It could be inferred that soil type and climate have more impact on bulk density and WSA than the management system. Most chemical soil properties did not show significant difference between management systems. However, labile soil C was significantly higher $(p<0.05)$ in organic systems and values were almost twice as high compared to conven-

Table 1. Location and soil description of surveyed banana farms in North Queensland, Australia [31] [32].

\begin{tabular}{|c|c|c|c|c|c|c|c|c|c|}
\hline Site & $\begin{array}{l}\text { Banana } \\
\text { system }\end{array}$ & Latitude & Longitude & $\begin{array}{c}\text { Rainfall } \\
(\mathrm{mm})\end{array}$ & Soil & Description & Drainage & Permeability & $\begin{array}{l}\text { Erosion } \\
\text { hazard }\end{array}$ \\
\hline Ric-O & Organic & $17^{\circ} 37^{\prime} 33^{\prime \prime}$ & $145^{\circ} 56^{\prime} 49^{\prime \prime}$ & 3482 & Ferrosol & Friable clay & Poor $^{1}$ & High $^{4}$ & $\operatorname{High}^{6}$ \\
\hline Fra-C & Conventional & $17^{\circ} 37^{\prime} 55^{\prime \prime}$ & $145^{\circ} 57^{\prime} 02^{\prime \prime}$ & 3482 & Ferrosol & Friable clay & Poor $^{1}$ & High $^{4}$ & Moderate $^{7}$ \\
\hline Frn-O & Organic & $17^{\circ} 51^{\prime 29 "}$ & $146^{\circ} 05^{\prime} 48^{\prime \prime}$ & 3149 & Ferrosol & Friable clay & Poor $^{1}$ & High $^{4}$ & High $^{6}$ \\
\hline Dol-C & Conventional & $17^{\circ} 51^{\prime} 58^{\prime \prime}$ & $146^{\circ} 05^{\prime} 57^{\prime \prime}$ & 3149 & Ferrosol & Friable clay & Poor $^{1}$ & $\operatorname{High}^{4}$ & Moderate \\
\hline Wat-O & Organic & $18^{\circ} 37^{\prime} 33^{\prime \prime}$ & $145^{\circ} 48^{\prime} 11^{\prime \prime}$ & 2426 & Dermosol & Friable clay & Imperfect $^{2}$ & Moderate $^{5}$ & Slight $^{8}$ \\
\hline Tod-C & Conventional & $18^{\circ} 03^{\prime} 50^{\prime \prime}$ & $145^{\circ} 49^{\prime} 27^{\prime \prime}$ & 2674 & Dermosol & Friable clay & Poor $^{1}$ & Moderate $^{5}$ & Slight $^{8}$ \\
\hline Grim-O & Organic & $17^{\circ} 34^{\prime} 42^{\prime \prime}$ & $146^{\circ} 00^{\prime} 03^{\prime \prime}$ & 3390 & Ferrosol & Friable clay & Poor $^{1}$ & High $^{4}$ & High $^{6}$ \\
\hline Dar-C & Conventional & $17^{\circ} 35^{\prime} 11^{\prime \prime}$ & $146^{\circ} 00^{\prime} 14^{\prime \prime}$ & 3390 & Ferrosol & Friable clay & Poor $^{1}$ & High $^{4}$ & Moderate $^{7}$ \\
\hline Dol-O & Organic & $17^{\circ} 07^{\prime} 39^{\prime \prime}$ & $145^{\circ} 22^{\prime} 57^{\prime \prime}$ & 967 & Ferrosol & Friable clay & Imperfect $^{2}$ & Moderate $^{5}$ & Moderate $^{7}$ \\
\hline How-C & Conventional & $17^{\circ} 06^{\prime} 19^{\prime \prime}$ & $145^{\circ} 24^{\prime} 47^{\prime \prime}$ & 924 & Ferrosol & Friable clay & Well $^{3}$ & $\mathrm{High}^{4}$ & Slight ${ }^{8}$ \\
\hline
\end{tabular}

${ }^{1}$ Water is removed very slowly; ${ }^{2}$ Water is removed only slowly in relation to supply; ${ }^{3}$ Water is removed from the soil readily but not rapidly; ${ }^{4}$ Vertical transmission of water though the soil profile would take 1 - 12 hours after thorough wetting to reach field capacity; ${ }^{5}$ Vertical transmission of water though the soil profile would take 1 - 5 days after thorough wetting to reach field capacity; ${ }^{6}$ Significant erosion can occur; ${ }^{7}$ Significant erosion can occur during development of a particular land use; ${ }^{8}$ No appreciable erosion damage is likely to occur. 
Table 2. Soil physical and chemical properties for organic and conventional soils sampled at selected banana farms ( $\mathrm{n}=5$ for both farm type) in north Queensland.

\begin{tabular}{|c|c|c|c|c|c|c|c|c|c|c|}
\hline \multirow{2}{*}{$\begin{array}{c}\text { Group } \\
\text { Physical indicators }\end{array}$} & \multirow{2}{*}{$\begin{array}{c}\text { Indicator } \\
\text { Bulk density }\end{array}$} & \multirow{2}{*}{$\begin{array}{l}\text { Unit } \\
\mathrm{kg} / \mathrm{l}\end{array}$} & \multicolumn{4}{|c|}{ Organic $\pm \mathrm{SE}$} & \multicolumn{4}{|c|}{ Conventional $\pm \mathrm{SE}$} \\
\hline & & & 1.14 & \pm & 0 & & 1.10 & \pm & 0 & \\
\hline & Clay & $\%$ & 19 & \pm & 1 & & 24 & \pm & 2.1 & \\
\hline & Sand & $\%$ & 50 & \pm & 1.3 & & 43 & \pm & 1.7 & \\
\hline & Silt & $\%$ & 31 & \pm & 0.9 & & 33 & \pm & 0.8 & \\
\hline & WSA & $\%$ & 90 & \pm & 0.7 & & 85 & \pm & 0.9 & \\
\hline \multirow[t]{21}{*}{ Chemical indicators } & $\mathrm{NH}_{3}$-Nitrogen & $\mathrm{mg} / \mathrm{kg}$ & 2.64 & \pm & 0.3 & & 2.08 & \pm & 0.1 & \\
\hline & Available potassium & $\mathrm{mg} / \mathrm{kg}$ & 167 & \pm & 25.3 & & 431 & \pm & 131.5 & \\
\hline & Boron & $\mathrm{mg} / \mathrm{kg}$ & 1.3 & \pm & 0.1 & & 1.7 & \pm & 0.3 & \\
\hline & Calcium & meq/100g & 9.1 & \pm & 0.7 & & 10.1 & \pm & 0.8 & \\
\hline & Cation exchange capacity & meq/100g & 12.2 & \pm & 1.2 & & 13.6 & \pm & 1 & \\
\hline & Chloride & $\mathrm{mg} / \mathrm{kg}$ & 12.1 & \pm & 1.8 & & 33.5 & \pm & 16.6 & \\
\hline & Copper & $\mathrm{mg} / \mathrm{kg}$ & 5.6 & \pm & 1.3 & & 4.5 & \pm & 1 & \\
\hline & Electrical conductivity & $\mu \mathrm{S}$ & 51 & \pm & 2.6 & & 106 & \pm & 6.8 & \\
\hline & Iron & $\mathrm{mg} / \mathrm{kg}$ & 51 & \pm & 10.1 & & 25 & \pm & 5.3 & \\
\hline & Labile C & $\mathrm{g} / \mathrm{kg}$ & 0.62 & \pm & 0 & $\mathrm{a}$ & 0.37 & \pm & 0 & $\mathrm{~b}$ \\
\hline & Magnesium & meq/100g & 2.3 & \pm & 0.2 & & 2.4 & \pm & 0.2 & \\
\hline & Manganese & $\mathrm{mg} / \mathrm{kg}$ & 35.8 & \pm & 5.8 & & 47.5 & \pm & 6.9 & \\
\hline & $\mathrm{NO}_{3}$-Nitrogen & $\mathrm{mg} / \mathrm{L}$ & 7.4 & \pm & 0.7 & & 11.6 & \pm & 1.2 & \\
\hline & Organic carbon & $\%$ & 2.4 & \pm & 0.2 & & 2.1 & \pm & 0.1 & \\
\hline & $\mathrm{pH}$ & & 6.65 & \pm & 0.1 & & 6.75 & \pm & 0.1 & \\
\hline & Phosphorouos (Colwell) & $\mathrm{mg} / \mathrm{kg}$ & 129 & \pm & 24.5 & & 241 & \pm & 42.3 & \\
\hline & Phosphorous buffer index & & 247 & \pm & 48.6 & & 325 & \pm & 40.2 & \\
\hline & Potassium & meq/100g & 0.42 & \pm & 0.1 & & 1.25 & \pm & 0.3 & \\
\hline & Sodium & meq/100g & 0.067 & \pm & 0 & & 0.047 & \pm & 0 & \\
\hline & Sulphate sulfur & $\mathrm{mg} / \mathrm{kg}$ & 15.5 & \pm & 2.2 & $\mathrm{~b}$ & 63.5 & \pm & 11 & $\mathrm{a}$ \\
\hline & Zinc (DTPA) & $\mathrm{mg} / \mathrm{kg}$ & 12 & \pm & 3.5 & & 12 & \pm & 1.6 & \\
\hline
\end{tabular}

Mean values are followed by standard errors and means with different letters following were significantly different from one another ( $p=0.05)$ determined using Fisher's protected LSD.

tional systems. Sulphate levels were significantly higher $(p<0.05)$ in conventional systems with values about four times higher compared to those measured in organic soils. There was a significant difference $(p<0.05)$ in microbial activity between management systems (Table 3), with both FDA and $\beta$-glucosidase levels being higher in organic soils. Moreover, nematode community structure was considerably different between organic and conventional systems (Table 3). The percentage of bacterial-feeding and fungal-feeding nematodes were a factor two and five times greater in organic systems, respectively, while the percentage of predatory and omnivorous nematodes was also more than twice as high in organic systems compared to conventional systems. The percentage of plant-parasitic nematodes in organic systems, on the other hand, was only half of that for conventional soils. The organic systems also demonstrated significantly greater $(p<0.05)$ nematode diversity (Table 3$)$. 
Table 3. Soil microbial and nematode properties for organic and conventional soils sampled at selected banana farms ( $\mathrm{n}=5$ for both farm type) in north Queensland.

\begin{tabular}{|c|c|c|c|c|c|c|c|c|c|c|}
\hline \multirow{3}{*}{$\begin{array}{c}\text { Group } \\
\text { Microbial } \\
\text { indicators }\end{array}$} & \multirow{3}{*}{$\begin{array}{c}\text { Indicator } \\
\beta \text {-glucosidase } \\
\text { Fluorescein diacetate }\end{array}$} & \multicolumn{2}{|l|}{ Unit } & \multicolumn{3}{|c|}{ Organic \pm SE } & \multicolumn{4}{|c|}{ Conventional $\pm \mathrm{SE}$} \\
\hline & & $\mu \mathrm{g}$ pNP released g/soil/h & 548 & \pm & 48.5 & $\mathrm{a}$ & 345 & \pm & 34.5 & $\mathrm{~b}$ \\
\hline & & $\begin{array}{l}\text { mg hydrolysed } \\
\text { FDA/kg soil/hr }\end{array}$ & 1.31 & \pm & 0.1 & $\mathrm{a}$ & 0.85 & \pm & 0 & $\mathrm{~b}$ \\
\hline \multirow{10}{*}{$\begin{array}{l}\text { Nematode } \\
\text { indicators }\end{array}$} & Bacterial feeding & $\%$ & 32 & \pm & 1.6 & $\mathrm{a}$ & 17 & \pm & 1.3 & $\mathrm{~b}$ \\
\hline & Bacterivore: fungivore ratio & & 0.71 & \pm & 0 & & 0.83 & \pm & 0 & \\
\hline & Channel index (CI) & & 24 & \pm & 1.5 & & 19 & \pm & 1.1 & \\
\hline & Diversity index $(\mathrm{H})$ & & 2.05 & \pm & 0 & $\mathrm{a}$ & 1.47 & \pm & 0.1 & $\mathrm{~b}$ \\
\hline & Endophytes & $\%$ & 27 & \pm & 3.8 & & 28 & \pm & 4.3 & \\
\hline & Enrichment index (EI) & & 74 & \pm & 1 & & 74 & \pm & 1.1 & \\
\hline & Fungal feeding & $\%$ & 14 & \pm & 1.5 & $\mathrm{a}$ & 3 & \pm & 0.2 & $\mathrm{~b}$ \\
\hline & Plant parasites & $\%$ & 31 & \pm & 2.2 & $\mathrm{~b}$ & 70 & \pm & 2.1 & $\mathrm{a}$ \\
\hline & Predatory and omnivorous & $\%$ & 20 & \pm & 1.3 & $\mathrm{a}$ & 10 & \pm & 1.2 & $\mathrm{~b}$ \\
\hline & Structure index (SI) & & 68 & \pm & 1.8 & & 69 & \pm & 1.6 & \\
\hline \multirow{2}{*}{$\begin{array}{l}\text { Disease } \\
\text { indicators }\end{array}$} & Fusarium plates & AUC & 8.2 & \pm & 0.4 & & 11.5 & \pm & 0.3 & \\
\hline & Tomato trials & AUC & 16.2 & \pm & 0.8 & $\mathrm{~b}$ & 19.6 & \pm & 1.0 & $\mathrm{a}$ \\
\hline
\end{tabular}

\subsection{Disease Suppression}

The hyphal extension tests did not show a significant difference in Foc hyphal growth between organic and conventional soils although the average hyphal growth of the conventional soils was numerically higher (Table 3). In terms of the incidence of $\mathrm{Fol}$, based on the results from the isolations of dead, diseased and healthy tomato plant tissue suggested that $\mathrm{Fol}$ was not the only pathogen present in the soil that potentially affected tomato plant health. Fol was isolated from dead plants of all soils. Other plant pathogens isolated from dead or diseased plants included Chalara spp., Curvularia lunata, Gliocladium spp., Phoma spp., Phomopsis spp., Pythium spp., Rhizoctonia spp., Sclerotinia spp. and Thielaviopsis spp. The bacterial wilt Ralstonia spp. was widespread and presents a serious limitation to tomato cultivation in the region. However, taking all these limitations into account, it appeared that after being exposed to a range of plant pathogens, organic soils demonstrated significantly better $(p<0.05)$ overall tomato plant health than conventional soils (Table 3 ).

The pot experiment did not demonstrate any significant difference $(p>0.05)$ in terms of plant growth or disease development between the management systems (Table 4). However, the average numeric value for most growth indicators was slightly higher and disease indicators were slightly lower in organic soils than in conventional soils. A principal component analysis (PCA) provided a more effective statistical tool for analysing and visualizing results (Figure 1). The PCA had a varimax rotation applied to latent vectors to determine the variables with the greatest loadings and an overview of the coefficients for specific variable is presented in Table 5. The first principle component (the horizontal axis), explained $72.5 \%$ of the variation in the data, where the variables leaf emergence, rhizome discoloration, leaf area and plant growth had the greatest vector loadings. Based on the emergence of variables within PC1 it may be concluded that the component was mainly based on the overall "growth" of the banana plants. The second principle component (the vertical axis), which explained $19.6 \%$ of the variation in the data, had wilting and root ratings showing the highest vector loadings. Therefore, the second principle component explains the level of "Fusarium" infection with the plants. The PCA bi-plot separated the site Grim-O from other sampling sites (Dar-C, Dol-O and How-C) included in the experiment. Based on the directions of the vectors it appeared that Grim-O had greater plant growth, leaf area and leaf emergence and was negatively correlated with Foc root ratings. Furthermore, Grim-O was neutral for rhizome discoloration and wilting AUC values (Figure 1). The How-C plants showed high wilting at low rhizome discoloration, whereas, the Dol-O showed low wilting at high rhizome discoloration values (Figure 1). 


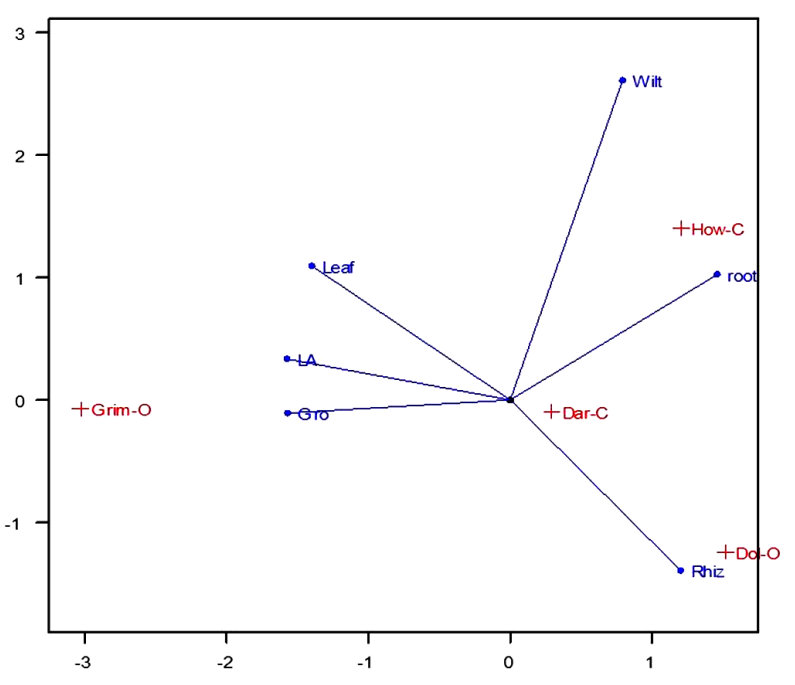

Figure 1. Principal component biplot of farm soils as function of disease and growth indicators. The red crosses represent farms, where: $\mathrm{O}$ refers to organic farms and $\mathrm{C}$ to conventional farm. Both Dol-O and How-C and Grim-O and Dar-C are farm pairs. Lines represent vectors which for proportion banana growth and disease variables, where: Gro = plant growth $\mathrm{cm} \mathrm{wk}^{-1}$, Leaf $=$ leaf emergence leaves $\mathrm{wk}^{-1}$, LA $=$ leaf area $\mathrm{cm}^{2}$, Rhiz $=$ discoloration of rhizome, Root $=$ discoloration of roots and Wilt $=$ wilting area under disease progress curve.

Table 4. Averages of growth and Fusarium wilt parameters of potted banana plants grown in a selection of organic and conventional soils identified from organic and conventional banana production in north Queensland.

\begin{tabular}{ccccccccc}
\hline \multirow{2}{*}{ Farm } & System & \multicolumn{2}{c}{ Discoloration } & & Wilting & $\begin{array}{c}\text { Growth } \\
\left(\mathrm{cm} \mathrm{week}^{-1}\right)\end{array}$ & $\begin{array}{c}\text { Leaf emergence } \\
\left(\text { leaves week }^{-1}\right)\end{array}$ & $\begin{array}{c}\text { Leaf area } \\
\left(\mathrm{cm}^{2}\right)\end{array}$ \\
\cline { 3 - 4 } & & Rhizome & Root & & & & \\
Dar-C & Conventional & 5.0 & 3.4 & 6.67 & 2.63 & 2.06 & 56.7 \\
Dol-O & Organic & 6.0 & 3.2 & 6.50 & 1.79 & 2.00 & 50.2 \\
Grim-O & Organic & 4.8 & 2.2 & 6.33 & 3.71 & 2.67 & 85.9 \\
How-C & Conventional & 5.3 & 3.7 & 8.00 & 1.88 & 2.29 & 56.6 \\
\hline
\end{tabular}

Table 5. Percentage variation based on principal components analysis with discriminate weighting functions for the separate growth and Fusarium wilt parameters of potted banana plants grown in a selection of organic and conventional soils identified from organic and conventional banana production in north Queensland.

\begin{tabular}{ccc}
\hline & PC1 & PC2 \\
\hline Percentage variation of rotated factors & $72.5 \%$ & $19.6 \%$ \\
Plant growth & 0.36 & -0.31 \\
Leaf area & 0.44 & -0.20 \\
Leaf emergence & 0.53 & 0.01 \\
Rhizome discoloration & -0.54 & -0.12 \\
Wilting & 0.28 & 0.77 \\
Root discoloration & -0.17 & 0.51
\end{tabular}

where: PC1 = Principal component 1, PC2 = Principal component. 


\subsection{Correlation between Soil Health Indicators and Plant Health Indicators}

Hyphal growth of Foc on soil in petri-dishes showed a negative correlation with the soil parameters bulk density, nematode diversity, and fungal feeding nematodes. A positive correlation was found between Foc hyphal extension, plant-parasitic nematodes numbers, soil organic carbon, copper, electrical conductivity and sulphate sulphur (data not shown). Area under disease curve (AUC) for tomatoes showed a negative correlation with nematode diversity, nematode community structure index and soil magnesium. Disease in tomatoes was positively correlated with soil potassium and sulphate levels. The height of potted banana plants was positively correlated with nematode diversity, organic carbon and phosphorus content of the soil, while it was negatively correlated with soil sulphate content. The leaf area of banana plants was positively correlated with soil phosphorus values while the reverse was true for rhizome discoloration. Wilting of potted banana plants was negatively correlated with nematode diversity (data not shown for more details see Geense [42]).

Multiple regression models were used to explain disease suppression. Fusarium hyphal growth AUC on soil plates appeared to be a function of nematode diversity, soil organic carbon and copper content (Equation (1)). This model could explain a majority of the variation and resulted in an $r^{2}$ value of $0.64(p<0.05)$, with the corresponding model equation:

$$
\text { AUC Foc hyphal growth }=29.4-17.1 \times \mathrm{H}-5.96 \times \mathrm{OC}+1.24 \times \mathrm{Cu}
$$

where $\mathrm{H}=$ nematode diversity,

OC = organic carbon $(\%)$,

$\mathrm{Cu}=\operatorname{copper}(\mathrm{mg} / \mathrm{kg})$.

In terms of tomato plant health, this appeared to be primarily a function of nematode diversity, soil potassium and magnesium content (Equation (2)). Including these parameters into a multiple regression model could account for greater than half the variation in the health of tomato plants with a combined $r^{2}$ value of $0.61(p<0.05)$ and the multiple regression model:

$$
\text { AUC Tomato disease }=23.69-2.1 \times \mathrm{H}-1.7 \times \mathrm{Mg}+2.4 \times \mathrm{K}
$$

where $\mathrm{H}=$ nematode diversity,

$\mathrm{Mg}$ = magnesium $(\mathrm{meq} / 100 \mathrm{~g})$,

$\mathrm{K}=$ potassium $(\mathrm{meq} / 100 \mathrm{~g})$.

\section{Discussion}

This study included farms using both organic and conventional banana systems in the main agro-climatic zones of the north Queensland banana industry, allowing conclusions relevant to the whole north Queensland banana production area. Organic banana farm practices in Australia were found to change soil biological properties, but had little impact on soil chemical properties while there was no change in soil physical properties. Physical soil properties in conventional and organic soils were very similar, especially within farm pairs. It appeared that WSA and bulk density are mainly influenced by climate and soil type, rather than management. Alternatively, it may also be that the soil management components including soil tillage that influence bulk density and WSA are implemented in rather similar manner in both management systems and are more indicative of the type of crop. As bananas in Australia are grown on a semi-perennial system being replanted every six to seven years, tillage was not expected to be a factor contributing to differences between the two systems.

Chemical properties of organic and conventional soils were similar, indicating similar application of nutrients, albeit in different forms. This may also be a reflection of the crops nutritional needs, rather than the form of fertiliser applied. The higher sulphate levels in the conventional soils may be explained by application of sulphur-based pesticides and fertilisers [43]. Additional studies are required for confirmation of this observation, but it seems likely that sulphate levels in soil may be used as an indicator of agrochemical and synthetic fertiliser use. The higher levels of labile soil $\mathrm{C}$ in the organic systems can be explained by increased emphasis on application of organic soil amendments, especially thoroughly composted, soluble or liquid organic fertilisers. Observations during the survey showed that organic banana farmers apply appreciable amounts of these types of fertiliser. Furthermore, organic farms typically foster soil organic matter additions by frequently including cover crops in their rotation, while the retention of crop residues was also more common compared to conventional farms.

Soil microbial activity indicators FDA and $\beta$-glucosidase were both higher in organic soils than in conven- 
tional soils. The majority of nutrients in conventional production are applied in mineral forms, which tend to be readily available to plants. Microorganisms involved in breakdown of organic materials thus lose a food source and their populations decline. Microorganisms engaged in the mineralisation process often have symbiotic interactions with plants, exchanging soil minerals for carbon. However, as plants already receive readily available nutrients in mineral form they no longer benefit from investing carbon in sustaining symbiotic relationships with microorganisms, and these organisms may lose their functionality. Furthermore, several studies have shown a clear relation between decline of soil microbial activity and the use of agrochemicals [44]-[46]. Moreover, all biocides potentially have a negative impact on soil biology. The underlying mechanisms are not entirely clear, but further investigation is required on the combined effects of reduced application of carbon and the antibiotic effects of agrochemicals creating an unfavourable environment for soil microbial activity in conventional agriculture.

The soil nematode community was closely related to soil microbial activity. In this survey it was observed that the percentage of bacterial-feeding, fungal-feeding, predatory and omnivorous nematodes in the organic soils were often a factor two or more times greater than for conventional soils. Higher levels of bacterial and fungal-feeding nematodes are indicative of higher levels of microbes, which translate to more intense cycling of nutrients, thereby creating a more dynamic, better balanced and healthier soil. The higher level of predatory nematodes indicated a higher degree of self-regulation of the soil nematode community [38]. This was also reflected in the diversity index that was significantly higher in organic systems. Increasing both above-ground and below-ground diversity in an ecosystem, increased dynamics, self-regulation and resilience of that system [24] [47]-[49]. At the conventional banana production sites the percentage of plant-parasitic nematodes was more than double that of the organic systems. In conventional soils, the balancing effect of diversity was weaker and there were less predatory nematodes to regulate the numbers of parasites, leaving the species that can cause economic damage to crops to proliferate.

It is of interest that the environment for beneficial microbes and nematodes was unfavourable in the conventional soils; however, the parasitic nematodes appeared to tolerate that environment. This is possibly because pathogens and parasites have adapted to these circumstances during their association with commercial crops obtaining carbon from root systems. For example, Abang et al. [50] found that pathogen evolution can develop very rapidly in monocultures. Furthermore, pathogens and parasites are less reliant on decomposing organic substrates than other soil micro- and macro-organisms. Co-evolution of host-pathogen systems may lead to local adaptation to environmental conditions of potential pathogens [51]. This effect becomes more pronounced if the pathogen has a greater adaptability and host prevalence is increased, as found in mono-cropped perennial systems [51].

Yardim and Edwards [52] found under field conditions that frequent use of fungicides, herbicides and insecticides caused a decrease in bacterial-feeding, fungal-feeding, predatory and omnivorous nematodes and an increase in plant-parasitic nematodes, which supports the results of the two-sided correlation tests in this study. Sulphate levels were also positively correlated with disease progress in tomatoes and to Foc hyphal growth. Plant-parasitic nematodes were also positively correlated with Foc hyphal growth. These correlations may provide additional evidence, from which may be concluded that the use of agrochemicals and synthetic fertilizers can foster plant-pathogens and parasites.

It is questionable if the Foc hyphal extension test described by Alabouvette et al. [29] provided a useful insight in soil Fusarium suppression. Firstly, hyphal growth of Fusarium does not guarantee successful infection and subsequent disease expression of the host plant [53]. Secondly, it was difficult to distinguish between different fungi on the plate, especially between Foc and other species of Fusarium. Especially in the second half of the test it was unclear if the Foc on the plug was colonizing the soil or that the fungi in the soil were colonizing the plug. Regardless, the test showed that Foc hyphal growth, probably as well as any other fungi, was favoured by soil organic carbon. From a management point of view this implies that to reduce Foc colonization, organic matter should only be applied if the material is well colonized by other saprophytic microorganisms or if there is sufficient microbial activity in the soil to colonize the material quickly, thereby effectively out-competing the pathogen.

The presence of other fungi and possibly bacteria that are pathogenic to tomatoes made it impossible to make a conclusive statement regarding soil Fusarium suppression. In this context, tomato may not be the most suitable crop to test soil Fusarium suppression because of its susceptibility to a wide range of other plant pathogens. Also, plant health is an important factor in Fusarium infection. Growing tomatoes in a banana soil therefore, may not 
give a clear picture of potential Foc suppression of a soil. Therefore, it would be preferable to use the specific host and pathogen of interest, or if impossible, to use a wider range of hosts and their associated (Fusarium) pathogens. Another issue was that the Fol R3 strain used had lost much of its pathogenicity, making it difficult to determine how suppressive soils were to the pathogen. However, the tomato bioassay did show that organic management could increase general soil suppression and overall plant health for at least this specific crop.

The principal component analysis of the banana pot trial showed that plant growth and Foc infection are to some extent determined by location and soil type. More specifically, one paired site clearly had less growth and more disease than the others (Figure 1). From the observation that one organic soil demonstrated better growth and reduced disease symptoms suggested that organic management can reduce the effects of Foc. The organic soil from the pair Dol-O and How-C had less wilting than its conventional counterpart, despite higher rhizome discoloration. It appeared that the soil from the organic system allowed plants to tolerate plant infection slowing disease symptom progress.

In all three experiments, hyphal extension test, tomato Fusarium suppression assay test and banana pot trial, nematode diversity and sulphate sulphur were recurring indicators with close correlation to respectively pathogen growth, disease expression and plant health. Foc hyphal extension and tomato disease development were negatively correlated with nematode diversity and positively correlated with sulphate sulphur. Banana plant growth was positively correlated with nematode diversity and negatively correlated with sulphate sulphur. Nematode diversity also played an important role in explaining variation of disease indicators in the multiple regression models. Based on current findings it appeared that nematode diversity, as an indicator of general soil biological diversity and soil sulphate, as an indicator of synthetic inputs may be suitable soil health indicators of suppression of Fusarium and Foc and in general soil health. However, further research is required to confirm these findings for other cropping scenarios.

\section{Conclusion}

It may be argued that stimulating soil microbial diversity and activity, thus increasing competition, can reduce soil pathogen conduciveness. Careful management of organic matter application and reduction or preferably omission of agrochemical use can achieve greater soil biodiversity and microbial activity. Agrochemicals, synthetic fertiliser use, lack of plant diversity and lack of regular organic matter inputs appeared to create soil conditions which were more conducive to plant-pathogens in bananas, specifically plant-parasitic nematodes and Foc. Conducive or suppressive soil conditions to Foc seem to be largely directed by competition for carbon. Soil suppression or promotion to Fusarium wilt of bananas is a complex issue that cannot be assessed by a single indicator. However, measurement of soil microbial enzyme activity, nematode community structure, diversity and possibly sulphate sulphur appeared to provide a reliable indication of general disease suppression for bananabased cropping systems.

\section{Acknowledgements}

This work was jointly funded by the Australian Centre for International Agricultural Research through project Hort/2008/040, with additional support from the Queensland Government through the Department of Agriculture, Fisheries and Forestry and the Biological Farming Systems Group, Wageningen University code number BFS-80436. The banana grower's in north Queensland who contributed to the survey are gratefully acknowledged for allowing this work to be conducted on their properties and the contribution they have made to ensure the experiment reached a conclusion. Thanks are also given to colleagues Dr. Leanne Forsyth, Mr. Mike Male, Mr. Lynton Vawdrey and Mr. David Astridge for their assistance and expert knowledge.

\section{References}

[1] Stirling, G.R. and Pattison, A.B. (2008) Beyond Chemical Dependency for Managing Plant-Parasitic Nematodes: Examples from the Banana, Pineapple and Vegetable Industries of Tropical and Subtropical Australia. Australasian Plant Pathology, 37, 254-267. http://dx.doi.org/10.1071/AP08019

[2] Kernot, I., Lindsay, S., Campagnolo, D., Daniells, J., Evans, D., Goebel, R., Gunther, M., Lemin, C., Pattison, T., Peterson, R., Pinese, B. and Wharton, D. (1998) Tropical Banana Information Kit. Department of Primary Industries, Nambour.

[3] Anonymous (2001) Great Barrier Reef Water Quality Action Plan. Great Barrier Reef Marine Park Authority, Towns- 
ville, 64. http://www.gbrmpa.gov.au/corp_site/key_issues/water_quality/action_plan/

[4] Pattison, A.B., Moody, P.W., Badcock, K.A., Smith, L.J., Armour, J.A., Rasiah, V., Cobon, J.A., Gulino, L.-M., Mayer, R. and Lindsay, S. (2008) Development of Key Soil Health Indicators for the Australian Banana Industry. Applied Soil Ecology, 40, 155-164. http://dx.doi.org/10.1016/j.apsoil.2008.04.002

[5] Rasiah, R.V., Armour, J.D., Moody, P.W., Pattison, A.B., Lindsay, S. and Florentine, S. (2009) Characterising and Improving the Deteriorating Trends in Soil Physical Quality under Bananas. Australian Journal of Soil Research, 47, 574-584. http://dx.doi.org/10.1071/SR08256

[6] Kleiese, Y., Prove, B., McShane, T., Moody, P. and Reghenzani, J. (1997) Nutrient Loss Study in the Johnstone River Catchment. Queensland Department of Primary Industries, Brisbane, 8.

[7] Moody, P.W. and Aitken, R.L. (1997) Soil Acidification under Some Tropical Agricultural Systems. 1. Rates of Acidification and Contributing Factors. Australian Journal of Soil Research, 35, 163-173. http://dx.doi.org/10.1071/S96069

[8] Pegg, K.G., Moore, N.Y. and Bentley, S. (1996) Fusarium Wilt of Banana in Australia: A Review. Australian Journal of Agricultural Research, 47, 637-650. http://dx.doi.org/10.1071/AR9960637

[9] Thusrston, H.D. (1998) Tropical Plant Diseases. 2nd Edition, American Phytopathological Society, New York.

[10] Singh, R.S. (2000) Diseases of Fruit Crops. Science Publishers Inc., USA.

[11] Marois, J.J. and Ploetz, R.C. (1990) Biological Control of Diseases Caused by Fusarium oxysporum. In: Ploetz, R.C., Ed., Fusarium Wilt of Banana, APS Press, 77-81.

[12] Dita, M.A., Waalwijk, C., Buddenhagen, I.W., Souza, M.T. and Kema, G.H.J. (2010) A Molecular Diagnostic for Tropical Race 4 of the Banana Fusarium Wilt Pathogen. Plant Pathology, 59, 348-357. http://dx.doi.org/10.1111/j.1365-3059.2009.02221.x

[13] Ploetz, R.C. (1994) Panama Disease: Return of the First Banana Menace. International Journal of Pest Management, 40, 326-336. http://dx.doi.org/10.1080/09670879409371908

[14] Ploetz, R.C., Thomas, J.E. and Slabaugh, W.R. (2003) Diseases of Banana and Plantain. In: Ploetz, R.C., Ed., Diseases of Tropical Fruit Crops, CABI Publishing, Wallingford, UK, 73-134. http://dx.doi.org/10.1079/9780851993904.0073

[15] Bancroft, J. (1876) Report of the Board Appointed to Enquire into the Cause of Disease Affecting Livestock and Plants. Queensland, 1876. Votes and Proceedings, 3, 1011-1038.

[16] Hennessy, C., Walduck, G., Daly, A. and Padovan, A. (2005) Weed Hosts of Fusarium oxysporum f. sp.cubense Tropical Race 4 in Northern Australia. Australasian Plant Pathology, 34, 115-117. http://dx.doi.org/10.1071/AP04091

[17] Meldrum, R.A., Fraser-Smith, S., Tran-Nguyen, L.T.T., Daly, A.M. and Aitken, E.A.B. (2012) Presence of Putative Pathogenicity Genes in Isolates of Fusarium oxysporum f. sp.cubense from Australia. Australasian Plant Pathology, 41, 551-557. http://dx.doi.org/10.1007/s13313-012-0122-x

[18] Pattison, A.B. and Lindsay, S. (2006) Banana Root and Soil Health User’s Manual. Department of Primary Industries and Fisheries, Brisbane.

[19] Smith, M.K., Whiley, A.W., Searle, C., Langdon, P.W., Schaffer, B. and Pegg, K.G. (1998) Micropropagated Bananas Are More Susceptible to Fusarium Wilt than Plants Grown from Conventional Material. Australian Journal of Agricultural Research, 49, 1133-1139. http://dx.doi.org/10.1071/A98013

[20] De Wit, J. and Verhoog, H. (2007) Organic Values and the Conventionalization of Organic Agriculture. NJAS-Wageningen Journal of Life Sciences, 54, 449-462.

[21] Kristiansen, P. and Merfield, C. (2006) Overview of Organic Agriculture. In: Kristiansen, P., Taij, A. and Reganold, J., Eds., Organic Agriculture, a Global Perspective, CAB International Publishing, Wallingford, 1-23.

[22] Fliessbach, A. and Mäder, P. (2000) Microbial Biomass and Size-Density Fractions Differ between Soils of Organic and Conventional Agricultural Systems. Soil Biology and Biochemistry, 32, 757-768. http://dx.doi.org/10.1016/S0038-0717(99)00197-2

[23] Lundquist, E.J., Scow, K.M., Jackson, L.E., Uesugi, S.L. and Johnson, C.R. (1999) Rapid Response of Soil Microbial Communities from Conventional, Low Input, and Organic Farming Systems to a Wet/Dry Cycle. Soil Biology and Biochemistry, 31, 1661-1675. http://dx.doi.org/10.1016/S0038-0717(99)00080-2

[24] Mäder, P., Fliessbach, A., Dubois, D., Gunst, L., Fried, P. and Niggli, U. (2002) Soil Fertility and Biodiversity in Organic Farming. Science, 296, 1694-1697. http://dx.doi.org/10.1126/science.1071148

[25] Lockie, S. and Halpin, D. (2005) The “Conventionalization” Thesis Reconsidered: Structural and Ideological Transformation of Australian Organic Agriculture. Sociologica Ruralis, 45, 284-307.

[26] Karlen, D.L., Ditzler, C.A. and Andrews, S.S. (2003) Soil Quality: Why and How? Geoderma, 114, 145-156. http://dx.doi.org/10.1016/S0016-7061(03)00039-9

[27] van Bruggen, A.H.C. and Semenov, A.V. (2000) In Search of Biological Indicators for Soil Health and Disease Sup- 
pression. Applied Soil Ecology, 15, 13-24. http://dx.doi.org/10.1016/S0929-1393(00)00068-8

[28] Alabouvette, C. (1990) Biological Control of Fusarium Wilts in Suppressive Soils. In: Hornby, D., Ed., Biological Control of Soilborne Plant Pathogens, CAB International Publishing, Wallingford, 27-43.

[29] Alabouvette, C., Raaijmakers, J.M., de Boer, W., Notz, R., Défago, G., Steinberg, C. and Lemanceau, P. (2006) Concepts and Methods to Assess the Phytosanitary Quality of Soils. In: Bloem, J., Hopkins, D.W. and Benedetti, A., Eds., Microbiological Methods for Assessing Soil Quality, CABI Publishing, Wallingford, 257-269.

[30] García-Ruiz, R., Ochoa, V., Viñegla, B., Hinojosa, M.B., Peña-Santiago, R., Liébanas, G., Linares, J.C. and Carreirra, J.A. (2009) Soil Enzymes, Nematode Community and Selected Physio-Chemical Properties as Soil Quality Indicators in Organic and Conventional Olive Oil Farming: Influence of Seasonality and Site Features. Applied Soil Ecology, 41, 305-314. http://dx.doi.org/10.1016/j.apsoil.2008.12.004

[31] Isbell, R.F. (1996) The Australian Soil Classification. CSIRO Publishing, Melbourne.

[32] Simpson, B., Blogg, D., Haydon, G., Ruddle, L., Beswick, A., Rayner, D., Grundy, M. and Smith, D. (2004) SafeGuage 1.1.4. Department of Natural Resources and Mines, Brisbane.

[33] Moody, P.W. and Cong, P.T. (2008) Soil Constraints and Management Package (SCAMP): Guidelines for Management in Tropical Upland Soils. Australian Centre for International Agricultural Research, Canberra, 86.

[34] Schnürer, J. and Rosswall, T. (1982) Fluorescein Diacetate Hydrolysis as a Measure of Total Microbial Activity in Soil and Litter. Applied and Environmental Microbiology, 43, 1256-1261.

[35] Eivazi, F. and Tabatabai, M.A. (1988) Glucosidases and Galacosidases in Soils. Soil Biology and Biochemistry, 20, 601-606. http://dx.doi.org/10.1016/0038-0717(88)90141-1

[36] Whitehead, A.G. and Hemming, J.R. (1965) A Comparison of Some Quantitative Methods Extracting Small Vermiform Nematodes from the Soil. Annals of Applied Biology, 55, 25-38. http://dx.doi.org/10.1111/j.1744-7348.1965.tb07864.x

[37] Yeates, G.W. and Bongers, T. (1999) Nematode Diversity in Agroecosystems. Agriculture, Ecosystems and Environment, 74, 113-135. http://dx.doi.org/10.1016/S0167-8809(99)00033-X

[38] Ferris, H., Bongers, T. and de Goede, R.G.M. (2001) A Framework for Soil Food Web Diagnostics: Extension of the Nematode Faunal Analysis Concept. Applied Soil Ecology, 18, 13-29. http://dx.doi.org/10.1016/S0929-1393(01)00152-4

[39] Orjeda, G. (1998) Evaluation of Musa Germplasm to Sigatoka Diseases and Fusarium Wilt. INIBAP Technical Guidelines. International Network for Improvement of Banana and Plantain, Montpellier, 60.

[40] Turner, D.W. (1972) Dry Matter Production, Leaf Area and Growth Analysis of Bananas. Australian Journal of Experimental Agricultural and Animal Husbandry, 12, 216-224. http://dx.doi.org/10.1071/EA9720216

[41] Payne, R.W., Murray, D.A., Harding, S.A., Baird, D.B. and Soutar, D.M. (2008) GenStat for windows (11th Edition) Introduction. VSN International, Hemel Hempstead.

[42] Geense, P. (2010) Soil Health in Organic and Conventional Banana Production and Its Effect on Fusarium Wilt of Bananas. Master's Thesis, Wageningen University, Wageningen.

[43] Balik, J., Kulhanek, M., Cerny, J., Szakova, J., Pavlikova, D. and Cermak, P. (2009) Differences in Soil Sulfur Fractions Due to Limitation of Atmospheric Deposition. Plant Soil Environment, 55, 344-352.

[44] Duah-Yentumi, S. and Johnson, D.B. (1986) Changes in Soil Microflora in Response to Repeated Applications of Some Pesticides. Soil Biology and Biochemistry, 18, 629-635. http://dx.doi.org/10.1016/0038-0717(86)90086-6

[45] Moeskops, B., Sukristiyonubowo, Buchan, D., Sleutel, S., Herawaty, L., Husen, E., Saraswati, R., Setyorini, D. and De Neve, S. (2010) Soil Microbial Communities and Activities under Intensive Organic and Conventional Vegetable Farming in West Java, Indonesia. Applied Soil Ecology, 45, 112-120. http://dx.doi.org/10.1016/j.apsoil.2010.03.005

[46] Singh, J. and Singh, D.K. (2005) Bacterial, Azotobacter, Actinomycetes and Fungal Population in Soil after Diazinon, Imidacloprid and Lindane Treatments in Groundnut (Arachis hypogaea L.). Journal of Environmental Science and Health, Part B: Pesticides, Food Contaminants, and Agricultural Wastes, 40, 785-800. http://dx.doi.org/10.1080/03601230500189725

[47] Elmqvist, T., Folke, C., Nyström, N., Peterson, G., Bengtsson, J., Walker, B. and Norberg, J. (2003) Response Diversity, Ecosystem Change and Resilience. Front Ecological Environment, 1, 488-494. http://dx.doi.org/10.1890/1540-9295(2003)001[0488:RDECAR]2.0.CO;2

[48] Kennedy, A.C. and Smith, K.L. (1995) Soil Microbial Diversity and the Sustainability of Agricultural Soils. Plant and Soil, 170, 75-86. http://dx.doi.org/10.1007/BF02183056

[49] Torsvik, V. and Øvreås, L. (2002) Microbial Diversity and Function in Soil: From Genes to Ecosystems. Current Opinion in Microbiology, 5, 240-245. http://dx.doi.org/10.1016/S1369-5274(02)00324-7 
[50] Abang, M.M., Baum, M., Ceccarelli, S., Grando, S., Linde, C.C., Yahyaoui, A., Zhan, J. and McDonald, B.A. (2006) Differential Selection on Rhynchosporium secalis during Parasitic and Saprophytic Phases in the Barley Scald Disease Cycle. Phytopathology, 96, 1214-1222. http://dx.doi.org/10.1094/PHYTO-96-1214

[51] Gandon, S. and Michalakis, Y. (2002) Local Adaptation, Evolutionary Potential and Host Parasite Coevolution: Interactions between Migration, Mutation, Population Size and Generation Time. Journal for Evolutionary Biology, 15, 451-462. http://dx.doi.org/10.1046/j.1420-9101.2002.00402.x

[52] Yardim, E.N. and Edwards, C.A. (1998) The Effects of Chemical Pest, Disease and Weed Management Practices on the Trophic Structure of Nematode Populations in Tomato Agroecosystems. Applied Soil Ecology, 7, 137-147. http://dx.doi.org/10.1016/S0929-1393(97)00036-X

[53] Cook, J.R. and Baker, K.F. (1983) The Nature and Practice of Biological Control of Plant Pathogens. American Phytopathological Society, St. Paul. 